\title{
TRANSFORMASI IDENTITAS AKTIVIS GERAKAN ISLAM
}

\author{
Aam Amirudin \\ Program Magister Ilmu Komunikasi \\ Universitas Pasundan Bandung \\ E-mail: aam.amirudin@unpas.ac.id
}

\begin{abstract}
The aim of this paper examines the phenomenon of process and direction of identity transformations of the Tarbiah movement activists that becomes the activist of political movement. As the qualitative research, the data is achieved by in-depth interview and participatory observation. Fourteen politicians from Tarbiah activists have become the informant for this research. The result shows that identity transformation has been experienced by Tarbiah movement activists. The identity transformation progressively persisted through; open-minded thoughts, enthusiastic effort to the value of universal truth, developing ideological awareness, and become the agent of change. Becoming the political activist has brought them to the positive contemplation through three stages, namely ruhiyyah, fikriah, and amaliah contemplation. There are also positive and progressive changes in the communication with the non-activists. After becoming the parliament member, verbal symbol becomes more flexible and realistic in term of the approach of problem solving. Being a politician has grown the transcendental awareness that this position is a fate, trusteeship, and temptation. In developing a good self-image Tarbiyah activists apply two strategies: Firstly, impression management by using and discarding personal front. Secondly, collaborative teamwork for image management. Those two management strategies are conducted in front of the non-activist apart from their community.
\end{abstract}

Keywords: identity transformation, communication construction, and phenomenology 


\section{PENDAHULUAN}

Partai Keadilan Sejahtera (PKS) mengukir prestasi mengejutkan dalam pemilu legislatif 2004. Sebagai underdog, partai ini berhasil mengumpulkan 8,3 juta suara $(7,4 \%)$ dengan 45 kursi di DPR RI dan menempati urutan ke enam dalam perolehan suara secara nasional. Bahkan di DKI Jakarta partai ini berjaya sebagai yang teratas, mampu menyingkirkan partai-partai besar seperti Golkar dan PDIP (Koran Tempo, 19 Juni 2004). Untuk sebuah partai yang tergolong baru (didirikan pada tangga 20 Juli 1998) pencapaian sebesar ini tentu cukup mencengangkan. Padahal pemilihan tahun 1999 hanya mendapatkan 6 kursi atau 1,4 juta pemilih, itupun sebagian diantaranya diperoleh dengan penggabungan sisa suara

Pada pemilu 2009, perolehan suara Partai Keadilan Sejahtera (PKS) meningkat menjadi 10,54 \% atau 59 kursi DPR RI. Peringkat PKS meningkat ke posisi empat dalam perolehan suara secara Nasional dan mampu menyalip peringkat partai Islam lainnya yang sudah mapan seperti PPP, PAN, PKB dan PBB. Sehingga PKS bisa diposisikan sebagai partai peringkat pertama dalam peringkat partai-partai yang berbasis keislaman. Meskipun sempat gagal dalam pemilu 1999, partai yang dimotori anakanak muda ini dengan cepat mengkonsolidasikan diri. Mereka dengan telaten membangun jaringan kader dan simpatisan. Kerja keras tanpa gembargembor ini akhirnya membuahkan hasil 45 kursi di DPR. Padahal pada pemilihan tahun 1999 hanya mendapatkan 6 kursi atau 1,4 juta pemilih, itupun sebagian diantaranya diperoleh dengan penggabungan sisa suara. Untuk sebuah partai yang tergolong baru (didirikan pada tangga 20 Juli 1998) pencapaian sebesar ini tentu cukup mencengangkan (Kompas, 25 Juni 2005).

Greg Fealy (dalam Machmudi, 2005: v-vii) menyebutkan lima hal penting yang membuat PKS menjadi unik, yaitu: Pertama, PKS mengambil sumber inspirasi ideologi dan organisasi utamanya dari luar dan menjadikan pemikiran Ikhwanul Muslimin di Mesir sebagai model acuan. Buku-buku Ikhwanul Muslimin banyak diterjemahkan dan diterbitkan oleh anggota-anggotanya, misalnya karya Hassan Al-Banna, Yusuf Qurdhawi, Sayyid Quthub, dll. Kedua, PKS adalah satu-satunya partai kader yang murni dalam politik Indonesia saat ini. PKS memiliki proses rekruitmen yang khusus dan ketat, dan seleksi anggota yang dapat menghasilkan kader-kader dengan komitmen tinggi dan disiplin. Karenanya 
PKS adalah satu-satunya partai yang mampu mengembangkan semacam kultur internal dan disiplin organisasi yang dalam pandangan akademisi di bidang politik diyakini bisa membawa pada proses demokrasi yang terkonsolidasi. Ketiga, PKS adalah satu-satunya partai yang memiliki jaringan pelayanan sosial yang luas dan efektif. PKS menjadikan program sosial sebagai bagian integral dari pengabdiannya. Dan yang keempat, PKS menjadikan moralitas dalam kehidupan publik sebagai program utama politik.

Kehadiran Partai Keadilan dalam kancah politik (Islam) Indonesia adalah sebuah fenomena yang mencengangkan. Partai ini tidak punya akar historis seperti Partai Bulan Bintang, yang sering disebutsebut bertalian dengan Masyumi. Juga tidak memiliki kaitan dengan ormas Islam seperti hubungan yang terjalin antara Partai Amanat Nasional (PAN) dengan Muhammadiyah dan Partai Kebangkitan Bangsa (PKB) dengan Nahdhatul Ulama. Partai Keadilan adalah sebuah partai yang sama sekali baru. Ia didirikan oleh anak-anak muda umumnya berusia dibawah 40 tahun dan dibangun dari sebuah kegiatan dakwah yang intens di kampus-kampus (Tempo, 18 Januari 1999).

Fenomena munculnya kalangan muda terdidik (Islam) yang berpolitik bukanlah sesuatu yang terjadi secara tibatiba. Jika kolonialisme Belanda melahirkan tokoh-tokoh muda seperti Soekarno, Mohammad Hatta, Syahrir, Sukirman Wirjosandjojo, Mohammad Natsir, Mohammad Roem, Wahid Hasyim dan sebagainya, yang kemudian tampil sebagai para pendiri dan pemimpin republik Indonesia. Maka kemunculan kalangan muda mantan aktivis kampus pada dasawarsa akhir 1990-an berkaitan erat dengan kebijakan dan politik Orde Baru dibawah Soeharto yang melakukan proses domestikasi politik terhadap Islam. Jangankan menyuarakan Islam sebagai dasar negara, menjadikan Islam sebagai asas dan simbol partai pun tidak diperbolehkan. Siapapun yang ingin menyuarakan Islam politik atau Islam Ideologis, yang berbeda dengan arus utama pandangan politik keislaman Orde Baru, harus melakukannya sembunyi-sembunyi. Jika tidak, maka dakwaan subversif dengan mudah bisa dijatuhkan.

Pemerintahan Orde Baru yang dimulai dengan terbitnya Surat Perintah Sebelas Maret (Supersemar) sebagai landasan kepemimpinan nasional yang dikembangkan waktu itu telah menempatkan faktor stabilitas nasional, stabilitas politik, penyederhanaan partai serta keamanan 
nasional sebagai faktor terpenting dan esensial bagi pembangunan nasional. Puncak kebijakan tersebut dengan digulirkannya UU Keormasan No.3 dan 5 tahun 1985 yang mengharuskan seluruh ormas dan orpol untuk menjadikan Pancasila sebagai satu-satunya asas dalam organisasinya. Karenanya, dikenal dengan Asas Tunggal. Pemberlakukan UU ini diharapkan bisa meredam atau membungkam ormas dan orpol yang berbasis Islam agar tidak mengganggu stabilitas nasional.

Pemerintah Orde Baru bukan hanya memandulkan ormas dan orpol, ternyata jauh sebelum diundangkannya UU keormasan, telah dikeluarkan SK Menteri Pendidikan dan Kebudayaan pada tahun 1974 yang bertujuan membungkam kegiatan-kegitan kemahasiswaan dengan diberlakukannya NKK/BKK (Normalisasi Kehidupan Kampus atau Badan Koordinasi Kemahasiswaan), yang mempersempit ruang gerak mahasiswa dalam menjalankan kegiatannya. Setiap aktivitas mahasiswa harus mendapat persetujuan pimpinan perguruan tinggi, dan pimpinan perguruan tinggi bertanggungjawab penuh atas segala kegiatan di kampusnya. Ketentuan ini ditetapkan dalam SK 028/1974 tentang NKK/BKK yang ditandatangani oleh
Menteri Pendidikan dan Kebudayaan Dr. Sjarif Thayeb (Suryadi, 1999:8).

Dengan

diberlakukannya NKK/BKK, maka terpasunglah aktivitas mahasiswa yang berbau politik. Kampus menjadi steril dari kegiatan politik praktis dan inilah yang diinginkan rezim Orde Baru saat itu. Terbatasnya ruang untuk mengembangkan wacana politik keislaman khususnya, dan politik secara keseluruhan pada umumnya, telah mendorong para pemikir dan aktivis Islam untuk mencari alternatif yang memungkinkan. Ada juga yang mengembangkan dengan cara mendiversifikasi makna politik. Akan tetapi, sebagian besar justru menoleh strategi jangka panjang, yaitu dengan meningkatkan kajian terhadap Islam dalam spektrum yang lebih dalam dan luas. Dalam konteks ini, masjid-mesjid kampus serta forum-forum studi menjadi alternatif yang dinilai strategis untuk melakukan kajian-kajian Islam secara mendalam dengan penghayatan dan aplikasi praktis dalam kehidupan sehari-hari. Dalam forum kajian ini juga dirajut silaturrahmi dan dibangun jejaring (networking) antar mesjid kampus serta para aktivisnya.

Forum studi yang dilakukan di kampus-kampus ini kemudian dikenal dengan istilah Usrah. Usrah dalam bahasa Arab artinya keluarga. Disebut demikian, 
karena mereka membuat kelompok pengajian dengan jumlah anggota yang relatif sedikit antara lima sampai sepuluh orang seperti jumlah anggota sebuah keluarga. Usrah dibina oleh seorang Murabbi (pembina), yang melakukan pembinaan secara rutin dan konsisten. Usrah pada awalnya merupakan bentuk kegiatan pendalaman Islam yang dilakukan oleh aktivis mahasiswa Islam di masjid Salman ITB pada tahun 70-an hingga awal 80-an. Kemudian berkembang menjadi model pembinaan di kampus-kampus umum seperti UNPAD, UI, IPB, dll.

Citra Usrah yang sangat populer dan elegan sebagai wadah kegiatan para aktivis mahasiswa Islam pada tahun 70-an, ternyata pada awal 80-an mengalami "pembusukan citra" dengan munculnya gerakan Komando Jihad pimpinan Imron. Karena Imron dan kelompoknya disinyalir sebagai aktivis yang tergabung dalam kegiatan Usrah. Maka pada awal 80-an istilah Usrah mulai ditinggalkan oleh para aktivis mahasiswa Muslim dalam berkegiatan di kampus. (Kuntowijoyo, 1993:63).

Dengan model kegiatan yang tidak jauh berbeda dengan Usrah, pada pertangahan 80-an muncullah kegiatankegiatan keislaman dalam kelompokkelompok kecil di kampus yang dikenal sebagai Gerakan Tarbiah. Gerakan ini cukup mendominasi model-model kegiatan keagamaan di kampus-kampus umum seperti UI, ITB, UNPAD, IPB, UGM, dll. (Damanik, 2002:18)

Gerakan Tarbiah secara sosiologis bisa dikategorikan sebagai gerakan sosial keagamaan. Menurut Stephen K. Sanderson (1993:532-533), gerakan keagamaan disebut juga dengan gerakan revitalisasi. Revitalisasi berarti suatu upaya untuk menciptakan eksistensi yang baru atau yang dibangkitkan kembali yang disesuaikan dengan keadaan atau tantangan sekarang yang lebih baik. Gerakan Revitalisasi biasanya terjadi dalam kondisi-kondisi ketegangan; ketika penindasan dan eksploitasi mencapai batas-batas yang tidak bisa ditolerir. Semua gerakan revitalisasi mengandung unsur keagamaan maupun unsur politik dalam ideologi dan stategi mereka untuk melakukan perubahan, akan tetapi campuran kedua unsur itu berbedabeda; ada gerakan yang sangat kental nuansa politisnya bahkan sampai pada batas radikal yang mengharapkan perubahan sosial dengan segera. Tetapi ada juga yang lebih kental nuansa religi-nya, dan lebih terarah kepada tujuan religius dalam spektrum gerakannya. 
Gerakan Tarbiah bisa dikategorikan sebagai tipe kedua seperti yang disebutkan Stephen K. Sanderson. Hal ini dikuatkan oleh pernyataan Bruinessen (2002:132), Gerakan Tarbiah dalam pembinaan terhadap para anggotanya menghindarkan diri dari pembahasan-pembahasan politik praktis yang bersifat konfrontatif dengan penguasa rezim Orde Baru. Penekanan pembinaan lebih pada bagaimana menjadi pribadi muslim yang berakhlak mulia, berilmu dan bermanfaat untuk lingkungannya. Karenanya, mereka cenderung santun dan giat belajar. Inilah yang menyebabkan mengapa sejak munculnya Gerakan Tarbiah pada pertengahan 1980 an hingga runtuhnya rezim Orde Baru para aktifis Gerakan Tarbiah tidak ada yang pernah ditahan atau dipenjarakan karena kasus subversi.

Sejak presiden Soeharto mundur tanggal 21 Mei 1998, maka terbukalah kesempatan bagi warga negara Indonesia untuk mengekspresikan aspirasi politiknya secara bebas. Paling tidak telah muncul 181 partai setelah jatuhnya rezim Soeharta, dan salah satunya adalah Partai Keadilan. Partai ini dideklarasikan 9 Agustus 1998. Dalam waktu lima bulan setelah dideklarasikan, partai ini telah merambah ke 23 provinsi Indonesia. Di tingkat Kabupaten telah terbentuk 200 dewan pimpinan daerah dan di kecamatan telah ada lebih dari 1.000 lebih pengurus ranting (Tempo, 18 Januari 1999).

Mengapa Partai Keadilan begitu cepat membangun jaringan partainya di seluruh Indonesia ? Pertanyaan ini terjawab oleh penelitian yang dilakukan Damanik (2002), Imdadun (2003), Machmudi (2005), yang menyimpulkan bahwa Partai Keadilan dibangun dan digerakkan oleh para aktivis yang berada dalam Gerakan Tarbiah pada saat rezim Soeharto berkuasa. Maka logis apabila dalam waktu lima bulan saja setelah dideklarasikan, kepengurusan partai telah berdiri hampir diseluruh provinsi Indonesia.

Mencermati apa yang dipaparkan di atas tampaklah ada suatu proses perpindahan gerakan; dari gerakan dakwah yang menghindarkan isu-isu politik praktis menjadi gerakan politik praktis yang secara nyata berbeda dengan gerakan awalnya (baca: Gerakan Tarbiah).

Artikel ini akan menelusuri arah dan bentuk perubahan tersebut, dengan meneliti realitas komunikasi yang berlangsung setelah seseorang masuk dalam gerakan politik terbuka dan penuh kompromi padahal sebelumnya berada dalam gerakan Tarbiah yang cenderung tertutup dan menghindari intrik politik. 


\section{METODE PENELLITIAN}

Penelitian ini menggunakan paradigma interpretif. Thomas Lindlof (1995:27) menyebut paradigma interpretif untuk merujuk pada penelitian komunikasi dengan metode kualitatif yang bertradisi fenomenologi.Mulyana

menyebut penelitian yang menggunakan paradigma interpretif dengan istilah perspektif subjektif. Paradigma interpretif bersifat subjektif, sehingga temuan-temuan yang diperoleh lebih merupakan gambaran gejala yang teridentifikasi di lapangan yang mengungkap relung-relung fenomena yang belum tersentuh oleh studi-studi ataupun teori-teori yang pernah ada.Tradisi fenomenologi menjelaskan makna pengalaman hidup sejumlah orang tentang suatu konsep atau gejala (Creswell 1998:51).

$$
\text { Bila mengikuti tradisi }
$$

fenomenologis, jumlah subyek penelitian bisa 10 orang dengan lokasi satu tempat ataupun tersebar (Creswell 1998:122).Sedangkan Maxwell (Alwasilah, 2003:147) tidak mempermasalahkan jumlah subyek, yang penting sabyek itu mampu mencerminkan kekhasan dari latar, individu atau kegiatannya.Berdasarkan pertimbangan ini, peneliti melakukan wawancara terhadap terhadap 14 orang informan.
Penelitian ini menjadikan para aktivis gerakan Tarbiah yang berada di Jawa Barat menjadi subyek penelitian. Subyek penelitian ini dipilih secara purposif berdasarkan atas peranan mereka dalam gerakan dakwah dan politik. Para aktivis yang menjadi subyek berdasarkan kebutuhan penelitian adalah mereka yang telah memenuhi kriteria berikut :

a. Menjadi aktivis gerakan Tarbiah minimal selama lima tahun dengan pertimbangan bahwa mereka telah melewati sejumlah pembinaan yang intens dari para mentornya.

b. Pernah masuk dalam kegiatan politik praktis baik sebagai pengurus partai ataupun sebagai anggota lagislatif minimal tiga tahun.

c. Pernah menjadi mentor dalam gerakan Tarbiah minimal tiga tahun

d. Pernah mengikuti training dakwah minimal 3 kali

Penelitian ini berupaya mendeskripsikan pengalaman-pengalaman hidup para aktivis gerakan Tarbiah yang diasumsikan memiliki mental dan fikiran yang normal, dinamis, inovatif, kreatif dan antisipatif, sehingga bisa diprediksi bahwa setiap apa yang dilakukannya selalu atas kesadaran subjektifnya. 
Obyek penelitian ini adalah transformasi identitas dan konstruksi komunikasi aktivis gerakan Tarbiah setelah menjadi aktivis gerakan politik. Penelitian ini menjadikan pernyataan dan tindakan sadar aktivis gerakan Tarbiah,yang merupakan hasil konstruksi manusia yang merepresentasikan persepsi tentang dunia sekitarnyasebagai sumber data primer. Sedangkan data sekundernya, dengan mempelajari berkas-berkas atau dokumendokumen, publikasi, juga beberapa kalangan di luar informan yang dijadikan sumber data.

Data penelitian diperoleh melalaui wawancara mendalam (in-deph in- terview) dengan dialog yang berlangsung cair, dikemas dalam sebuah percakapan bebas namun dalam kolidor tema yang telah ditentukan oleh peneliti. Juga melakukan observasi pada kegiatan-kegiatan informan serta menelaah sejumlah dokumen yang akan memperkaya data penelitian.

\section{HASIL PENELITIAN DAN PEMBAHASAN}

Penelitian ini didasarkan pada penelitian atas gerakan Islam dengan memusatkan pada fenomena gerakan Tarbiah yang dianggap sebagai realitas sosial keagamaan yang kompleks.
Menggunakan pendekatan multiteoretis sebagai panduan untuk membedah persolan ini, yaitu teori fenomenologi Alfred Schutz, teori interaksi simbolik George Herbert Mead, teori konstruksi sosial Peter Berger dan Thomas Luckman, dan teori dramaturgis Erving Goffman. Teori-teori tersebut dapat digunakan untuk membedah realitas komunikasi (Littlejohn 2002:159) dalam gerakan keagamaan. Empat teori ini berbasis pada paradigma yang disampaikan Max Weber dalam Teori Tindakan Sosial (Mulyana 2003:61), yang menyatakan bahwa tindakan manusia pada dasarnya bermakna, melibatkan penafsiran, berfikir dan sengaja.

Apa yang dilakukan para aktivis Gerakan Tarbiah diyakini berbasis pada paradigma ini, mereka melakukannya dengan sadar, penuh makna dan sengaja. Atas dasar ini, maka peneliti menggunakan teori-teori tersebut sebagai pemandu untuk menganalisis realitas dan fenomena komunikasi para aktivis Gerakan Tarbiah.

Menjadi aktivis gerakan politik atau menjadi politikus akan memberikan implikasi dalam kehidupan aktivis gerakan Tarbiah. Setelah aktivis gerakan Tarbiah menjadi anggota parlemen atau menjadi politikus tentu terjadi pandangan yang berubah dari masyarakat terhadap dirinya 
dan ini akan memberikan implikasi pada pribadi aktivis gerakan Tarbiah itu sendiri. Implikasi yang berdimensi psikis ini dikenal dengan transformasi identitas.

Transformasi identitas yang disebabkan oleh perubahan status dari aktivis gerakan Tarbiah (da'i) menjadi aktivis politik (politikus) itu akan membuat perubahan konsep diri. Transformasi identitas merupakan transformasi situasional. Transformasi identitas menurut Mead (Mulyana, 2002:231) adalah transformasi yang menyangkut perubahan psikologis, di mana pelakunya menjadi orang yang berbeda dari sebelumnya. Transformasi mengisyaratkan penilaian baru tentang diri pribadi dan orang lain, tentang peristiwa-peristiwa, tindakan-tindakan, dan objek-objek (Strauss, 1959:92).

Transformasi identitas sebagai perubahan yang bersifat situasional tentu berlangsung dan dirasakan berbeda oleh setiap aktivis gerakan Tarbiah. Perbedaan tersebut dimungkinkan karena setiap individu berinteraksi dengan lingkungan sosial yang berbeda, dan memaknai setiap respon lingkungan dengan cara yang berbeda pula. Dalam perspektif interaksi simboliknya Mead dan juga makna konsep diri dari Cooley (Mulyana, 2002:74), pemaknaan seseorang tentang penilai orang lain (lingkungan) tentang dirinya merupakan faktor yang menentukan konsep diri yang bersangkutan. Dengan demikian dapat diasumsikan bahwa proses dan arah transformasi identitas seorang aktivis Tarbiah yang menjadi aktivis politik atau politikus berlangsung secara dinamis sebagaimana dinamisnya interaksi sosial yang mereka jalani. Merujuk kepada makna konsep diri dari Mead dan Cooley di atas, maka dapat diasumsikan bahwa dalam berinteraksi sosial, aktivis gerakan Tarbiah terus menerus menilai dan memaknai dirinya berdasarkan bagaimana penilaian dan pemaknaan orang lain yang dia pahami.

Identitas objektif dan subjektif (Berger dan Luckmann, 1990) merupakan dua jenis identitas yang senantiasa ditampilkan dalam interaksi sosial aktivis gerakan Tarbiah. Identitas objektif sebagai aktivis Tarbiah yang cenderung "menjauhi" dunia berupa perebutan kekuasaan, kehidupan yang penuh intrik dan perburuan materi, sebagai identitas yang telah mendapat legitimasi dari masyarakat diasumsikan senantiasa "disembunyikan" oleh para aktivis Tarbiah. Pada saat yang bersamaan identitas subjektifnya lebih ditonjolkan dengan cara melakukan pengelolaan kesan (Goffman, 1959) tertentu sehingga dapat membangun kesan seolah- 
olah mereka adalah politikus yang professional dan membela hak-hak rakyat. Kecenderungan untuk mengorientasikan diri sebagai politikus sejati inilah yang oleh Davis (1972) disebut sebagai upaya normalization. Manusia, sejak lahir telah mengkoleksi berbagai pengalaman dan nilainilai yang dijadikan sebagai referensi dalam menjalani hidup atau menyelesaikan persoalan yang dihadapi dalam hidupnya. Pengalaman dan nilai serta tradisi tersebut menurut Schutz (Musgrove, 1977) diistilahkan dengan recipe knowledge. Dalam konteks komunikasi, recipe knowledge dapat dimaknai sebagai tradisi dan budaya komunikasi yang telah terbiasa dilakukan oleh seseorang. Di samping berimplikasi pada transformasi identitas, menjadi politikus berimplikasi juga pada perubahan pola komunikasi aktivis Tarbiah. Perubahan pola komunikasi aktivis Tarbiah tidak terlepas dari tradisi lama (recipe knowledge) saat mereka belum menjadi politikus. Konsekwensinya, aktivis Tarbiah melakukan konstruksi komunikasi baru yang relevan dengan kondisi yang dialaminya sekarang sebagai politikus.

Asumsi ini sesuai dengan kriteria tindakan sosial yang dikemukakan Weber (Schutz, 1972) yang mengatakan bahwa perilaku seseorang dapat dikategorikan sebagai tindakan sosial bilamana yang bersangkutan memberi makna subjektif terhadap apa yang dilakukannya. Konsep realitas sosial dalam teori konstruksi sosial Berger dan Luckmann juga dapat menjelaskan fenomena konstruksi komunikasi aktivis Tarbiah. Individu dalam pandangan Berger dan Luckmann (Basrowi dan Sukidin, 2002:194) adalah manusia bebas yang melakukan hubungan antara manusia yang satu dengan yang lain, di mana individu menjadi penentu dalam dunia sosial yang dikonstruksi berdasarkan kehendaknya. Tradisi dan konstruksi komunikasi yang secara subjektif dilakukan oleh aktivis Tarbiah inilah yang antara lain menjadi salah satu fenomena yang ditelusuri dalam penelitian ini.

Dalam kehidupannya sebagai politikus, aktivis Tarbiah diprediksikan akan berkomunikasi dengan beberapa mitra komunikasi seperti dengan Tuhan, sesama aktivis, dan dengan non aktivis. Berdasarkan konteksnya, jumlah peserta yang terlibat, dan juga jenis mitra komunikasi, maka dikenallah beberapa jenis komunikasi, seperti komunikasi intrapribadi, komunikasi antarpribadi, komunikasi transendental, dan jenis-jenis komunikasi lainnya (Mulyana, 2002:70). Sebagaimana manusia pada umumnya, aktivis Tarbiah pun diasumsikan 
melakukan komunikasi dalam berbagai konteks dan ruang.

Komunikasi transendental juga menjadi realitas komunikasi yang mungkin dikonstruksi oleh aktivis Tarbiah, terutama setelah menjadi politikus. Komunikasi transendental dimaknai sebagai komunikasi antara manusia dengan Tuhan (Mulyana, 1999), atau yang oleh Izutsu (1997) disebut sebagai relasi komunikatif antara Tuhan dan manusia, yaitu relasi komunikatif yang bersifat nonlinguistik dan linguistik. Komunikasi transendental dimungkinkan untuk dikonstruksi oleh aktivis Tarbiah karena kondisi psikis mereka setelah menjadi politikus yang dinilai dekat dengan dunia "abu-abu" bahkan "hitam". Hal ini memungkinkan mereka mencari ketenangan spiritual dengan semakin mendekatkan diri (berkomunikasi) dengan Tuhannya. Kecenderungan ini relevan dengan makna agama secara fungsional (Rakhmat, 2004), dimana seseorang selalu mengkaitkan agama dengan upayanya untuk menjawab masalahmasalah kehidupan.

\section{Proses Transformasi Identitas}

Berdasarkan hasil penelitian, para informan tidak langsung begitu saja mengambil keputusan menjadi aktivis gerakan Tarbiah. Terdapat proses "menjadi" yang bersifat sosio historis seiring perjalanan kehidupan yang dilalui. Terdapat dua aspek dalam proses transformasi identitas menjadi aktivis gerakan Tarbiah yaitu Aspek Pendorong dan Aspek Penarik Seperti halnya menjadi aktivis gerakan Tarbiah yang mengalami "proses", maka berdasarkan hasil penelitian, para informan aktivis gerakan Tarbiah tidak langsung begitu saja mengambil keputusan menjadi aktivis gerakan politik. Terdapat proses "menjadi" yang bersifat sosio historis seiring perjalanan kehidupan yang dilalui. Terdapat dua aspek dalam proses transformasi identitas menjadi aktivis gerakan politik yaitu Aspek Pendorong dan Aspek Penarik

Pertama, Aspek pendorong yang dimaksud disini adalah suatu keadaan yang memicu mereka untuk memiliki daya atau tenaga tambahan untuk menjadi aktivis gerakan politik. Aspek-aspek pendorong yang teridentifikasi berdasarkan penelitian ini adalah: Pertama, keyakinan bahwa Islam itu agama yang harus melahirkan perubahan. Kedua, adanya keyakinan bahwa dakwah dan politik itu tidak bisa dipisahkan. Ketiga, adanya keyakinan bahwa gerakan politik bisa menjadi sarana investasi amal shaleh. Keempat, bahwa gerakan politik sebagai sarana untuk meraih kesempurnaan keislaman. Keempat aspek ini sifatnya 
bukan saling meniadakan tetapi saling melengkapi. Artinya ada informan yang hanya terdorong oleh satu aspek saja namun ada juga informan yang terdorong pleh beberapa aspek sekaligus.

Kedua, Aspek penarik yang dimaksud disini adalah aspek yang menjadi magnet bagi informan aktivis gerakan Tarbiah untuk terus berkiprah bahkan menjadi politikus sejati dalam gerakan politik. Aspek-aspek penarik yang teridentifikasi berdasarkan penelitian ini adalah adanya ketaatan pada qiyadah atau kepemimpinan, keyakinan bahwa Islam tidak bisa dipisahkan dari politik dan keyakinan bahwa dengan politik kegiatan dakwah bisa dilaksanakan dengan pendekatan kelembagaan. . Tiga aspek penarik ini satu sama lain bukan saling meniadakan tetapi bersifat saling melengkapi. Ada informan yang hanya tertarik dengan satu aspek saja namun ada juga yang tertarik oleh tiga aspek yang teridentifikasi itu.

\section{Arah Transformasi Identitas}

Hasil penelitian ini menunjukkan adanya dinamika arah transformasi identitas para aktivis gerakan Tarbiah sesudah menjadi aktivis gerakan pilitik. Para aktivis memperlihatkan kecenderungan sikap yang berbeda dalam setiap tahapan. Bertolak dari kecenderungan yang berbeda itulah penulis menamakan tahapan-tahapan tersebut dengan istilah yang berbeda pula, yaitu: terbuka fikiran, bergairah, tumbuh kesadaran ideologis, dan menjadi agen perubahan. Empat tahapan arah transformasi ini tentu saja tidak bersifat linear atau kronologis tetapi bersifat tumpang tindih karena proses transformasi identitas para aktivis tidak terlepas dari sifat manusia yang memiliki kecenderungan beragam, berkemauan bebas, kreatif, aktif, dan berbagai subjektif lainnya.

Selain itu, komunikasi aktivis dalam konteks penelitian ini dimaknai sebagai komunikasi dinamis, dimana sang aktor sebagai pelaku senantiasa aktif mengkonstruksi setiap komunikasi yang dilakukannya. Aktor komunikasi dalam penelitian ini adalah aktivis gerakan Tarbiah yang terjun ke dunia politik dan otomatis memposisikan mereka menjadi aktivis politik. Konsekwensinya, dunia politik adalah dunia baru bagi para aktivis dakwah ini. Oleh karena itu budaya komunikasi aktivis akan senantiasa diinternalisasi, berbarengan dengan melakukan konstruksi berdasarkan pemaknaan subjektifnya tentang kehidupan politik. Pada bagian ini akan diuraikan komunikasi aktivis gerakan Tarbiah dengan para mitra komunikasinya, yaitu komunikasi dengan dirinya, 
komunikasi dengan sesama aktivis, komunikasi dengan non aktivis serta komunikasi dengan Tuhan.

Dalam konteks penelitian ini, fenomena komunikasi aktivis gerakan Tarbiah dengan dirinya tersebut disebut dengan "kontemplasi". Istilah ini lebih tepat untuk menggambarkan sikap aktif, dinamis, dan subjektif aktivis gerakan Tarbiah dalam melakukan komunikasi. Dengan demikian, kontemplasi diri terkait dengan aktivitas sadar seseorang, atau yang oleh DeVito (1997:59) dianggap sebagai salah satu cara menumbuhkan kesadaran diri, di mana kesadaran diri merupakan landasan bagi semua bentuk dan fungsi komunikasi.

Latar belakang yang berbeda dari masing-masing aktivis antara lain membuat dinamika kontemplasi diri mereka cukup variatif. Berdasarkan materi kontemplasi yang mereka lakukan, peneliti membedakan kontemplasi diri aktivis dalam tiga jenis, yaitu kontemplasi ruhiyyah, kontemplasi fikriyyah dan kontemplasi amaliah. Tiga jenis kontemplasi diri aktivis ini hanya mempresentasikan tiga kecenderungan materi dialog mereka dengan dirinya. Munculnya tiga jenis kontemplasi tersebut bukan berarti bahwa aktivis hanya membicarakan tiga hal tersebut dalam hidupnya.
Kemudian juga munculnya identitas ganda dan pengelolaan kesan sebagai aktivis politik Islam. Seseorang yang menjadi aktivis politik dalam adalah individu yang sedang menjalani dua identitas; identitas sebagai aktivis tarbiah dan identitas sebagai politikus. Perubahan indentitas diawali dengan terpilihnya sebagai anggota legislatif. Peristiwa tersebut sekaligus menandai dimulainya lembaran hidup baru bagi aktivis gerakan Tarbiah; hidup dengan identitas aktivis politik atau politikus. Identitas politikus merupakan identitas yang didasarkan atas statusnya sebagai anggota parlemen. Dalam konteks inilah identitas diri ganda ditampilkan oleh aktivis gerakan Tarbiah.

1) Identitas Aktivis Tarbiah (Da’i)

Identitas aktivis Tarbiah merupakan identitas yang melekat dalam diri aktivis Tarbiah. Identitas tersebut dalam konteks penelitian ini lebih dekat dengan istilah identitas objektif dari Berger dan Luckmann (1990:235), yang mereka maknai sebagai identitas yang berasal dari legitimasi struktur kemasyarakatan dan telah menjadi pengetahuan umum mayoritas masyarakat. Oleh karena itu, identitas da'i dalam konteks penelitian ini dapat juga disebut dengan identitas objektif atau diri objektif. Dalam pengamatan peneliti, aktivis Tarbiah 
menampilkan diri objektifnya ketika berada dalam komunitasnya, atau di depan orangorang yang telah mengetahui identitasnya. Dalam liqa, daurah, dan mabit, para aktivis Tarbiah terlihat berinteraksi, dan berkomunikasi seperti apa adanya.

2) Identitas Politikus

Identitas politikus adalah identitas situasional. Dikatakan demikian sebab menjadi politikus khususnya dalam penelitian ini menjadi anggota parlemen terikat oleh masa jabatan. Kalau identitas aktivis tarbiah atau da'i merupakan identitas objektif yang dipahami oleh aktivis Tarbiah dan ditampilkan apa adanya di depan komunitas (in-group) dan orang lain yang telah mengenalnya sebagai aktivis Tarbiah, sedangkan identitas politikus, yang identik dengan identitas subjektif versinya Berger dan Luckmann (1990:235) merupakan identitas yang dihadirkan atau dikonstruksi oleh aktivis Tarbiah dalam situasi dan dengan motif tertentu.

Identitas subjektif hadir dilatarbelakangi oleh keinginan para aktivis Tarbiah menampilkan sosok politikus yang selalu berpihak pada kepentingan rakyat dan kritis terhadap penguasa. Oleh karena itu, munculnya identitas subjektif ditandai oleh adanya upaya mereka untuk mengkonstruksi realias-realitas tertentu, yang antara lain dengan cara mengelola kesan agar orang lain yang melihatnya (mitra komunikasinya) yakin bahwa mereka politikus yang bersih, jujur, profesional, bijak dan elegan.

Aktivis Tarbiah sadar bahwa menjadi politikus adalah amanah yang harus dipertaqnggungjawabkan di hadapan manusia pemilihnya dan di hadapan Tuhannya. Seiring dengan kesadaran ini, maka gairah mempelajari tugas-tugas serta menerapkan nilai-nilai kejujuran dan profesionalisme sebagai politikus semakin meningkat. Peningkatan ini bukan hanya terlihat dalam permukaan saja dalam bentuk kerja keras dan siap menerima resiko tetapi juga menjadi sebuah kesadaran ideologis yang menghunjam dalam jiwa aktivis. Konsekwensinya lahirlah jiwa yang penuh semangat untuk melakukan perubahanperubahan baik perubahan dalam dirinya ataupun perubahan di masyarakat sesuai perannya sebagai anggota parlemen.

Sebagai manusia subjektif dan memiliki kemauan bebas, aktivis Tarbiah melakukan konstruksi realitas dan budaya secara bebas berdasarkan keinginan dan kemauan subjektifnya. Hal ini relevan dengan eksistensi manusia dalam pandangan Berger dan Luckmann (Sukidin, 2002:194) lewat teori konstruksi sosial atas realitasnya sebagaimana dapat dikutip sebagai berikut: 
...individu adalah manusia bebas yang melakukan hubungan antara manusia yang satu dengan yang lain. Individu menjadi penentu dalam dunia sosial yang dikonstruksi berdasarkan kehendaknya. Individu bukan korban fakta sosial, namun sebagai mesin produksi sekaligus reproduksi yang kreatif dalam mengkonstruksi dunia sosialnya

Kehidupan parlemen adalah kehidupan baru bagi aktivis. Pengalaman baru ini (recipe knowledge), membuat transformasi psikis (pembangunan kepercayaan diri) pada aktivis semakin cepat atau cenderung meningkat (progresif), karena mereka menemukan komunitas baru (kehidupan parlemen) sebagai sarana proses pembelajaran. Proses belajar ini sebagai langkah awal yang dilakukan oleh aktivis untuk meniti dan membangun karier baru sebagai politikus.

Transformasi progresif terus bergerak ke arah yang lebih maju, setelah aktivis Tarbiah belajar "dunia baru" (kehidupan parlemen), berbarengan dengan itu gairah perjuangan pun meningkat Bertambahnya pengetahuan aktivis akan dunia politik membawa progresifitas kematangan emosi atau psikis aktivis. Pada awalnya dalam forum rapat di parlemen mereka berbicara hitam putih sesuai ajaran- ajaran agama yang hitam putih apa adanya, namun dengan perjalanan proses pembelajaran di parlemen, mereka mulai lebih lentur dalam menyampaikan pemikiran-pemikirannya tentu tanpa mengubah substansi ideologis yang diyakininya Kedewasaan emosi membuat mereka tidak lagi terlalu mempersoalkan (memikirkan) identitas yang disandangnya sebagai da'i atau aktivis Tarbiah, sehingga semakin hari mereka semakin percaya diri, termasuk percaya diri untuk tampil sebagai politikus profesional. Sebagai puncak dari transformasi progresif, aktivis memperlihatkan diri sebagai agen perubahan, yaitu manusia yang bisa bekerja secara produktif, jujur, bersih dan profesional sekalipun mereka sebenarnya miskin dengan pengalaman sebagai politikus, namun sikap profesionalitasnya ini bahkan bisa mengalahkan anggota parlemen yang sudah malang melintang dalam dunia politik. Seluruh upaya aktif dan sadar yang dilakukan oleh aktivis Tarbiah semakin memperlihatkan bahwa aktivis Tarbiah sebagai manusia transformatif.

\section{KESIMPULAN}

Fenomena gerakan Tarbiah yang dianggap sebagai realitas sosial keagamaan yang kompleks. Apa yang dilakukan para aktivis Gerakan Tarbiah diyakini berbasis 
pada paradigma bahwa mereka melakukannya dengan sadar, penuh makna dan sengaja. Sesudah aktivis gerakan Tarbiah menjadi menjadi politikus tentu akan terjadi pandangan yang berubah dari masyarakat terhadap dirinya dan ini akan memberikan implikasi pada pribadi aktivis gerakan Tarbiah itu sendiri. Implikasi yang berdimensi psikis ini sebagai bentuk transformasi identitas. Transformasi identitas sebagai perubahan yang bersifat situasional ini berlangsung dan dirasakan berbeda oleh setiap aktivis gerakan Tarbiah. Penelitian ini menyimpulkan beberapa fenomena transformasi, yaitu;

Pertama, arah transformasi identitas para aktivis gerakan Tarbiah sesudah menjadi aktivis gerakan politik memperlihatkan kecenderungan sikap berbeda dalam setiap tahapan, yaitu: terbuka fikiran, bergairah, tumbuh kesadaran ideologis dan menjadi agen perubahan. Empat arah transformasi ini tentu saja tidak bersifat linear atau kronologis tetapi bersifat tumpang tindih. Pandangan subjektif aktivis gearakan Tarbiah mengenai identitas yang disandangnya sebagai aktivis Tarbiah juga identitasnya sebagai aktivis politik dalam penelitian ini ditemukan empat makna, yaitu: (a) Makna Tarbiah dalam pandangan aktivis gerakan Tarbiah; (b) Makna aktivis
Tarbiah dalam pandangan dan pemaknaan aktivis gerakan Tarbiah; (c) Makna Politik dalam pandangan aktivis gerakan Tarbiah; dan (d) Makna aktivis politik dalam pandangan dan pemaknaan aktivis gerakan Tarbiah.

Kedua, konstruksi komunikasi aktivis gerakan Tarbiah setelah menjadi aktivis gerakan politik bisa ditinjau dalam empat konteks, yaitu; (a) Konteks komunikasi dengan diri sendiri; posisi sebagai aktivis politik membawa pada kontemplasi positif. (b) Konteks komunikasi dengan non aktivis; para aktivis Tarbiah mengalami perubahan ke arah yang positif dan progresif. (c) Konteks komunikasi dengan sesama aktivis; komunikasi para aktivis Tarbiah mengalami intensitas yang lebih meningkat, dan terjadi soliditas yang lebih kuat lagi. (d) Komunikasi dengan Tuhan juga mengalami progresivitas. Posisi sebagai politikus dimaknai secara transndental yaitu tumbuhnya kesadaran bahwa jabatan itu merupakan takdir, menyadari bahwa posisi politikus sebagai amanah yang harus ditunaikan dengan kejujuran dan sebagai ujian yang harus dilaksanakan dengan profesional.

Ketiga, aktivis gerakan Tarbiah yang masuk dalam gerakan politik telah mengalami transformasi identitas secara 
progresif. Transformasi progresif identik dengan hal-hal yang produktif dan berkonotasi positif. Dalam transformasi progresif, aktivis Tarbiah menampilkan diri sebagai manusia aktif dan sadar, serta senantiasa memberi makna subjektif terhadap setiap aktivitas yang dilakukannya. Kesadaran diri inilah yang menjadi awal perilaku aktifnya untuk melakukan perubahan (transformasi) ke arah yang lebih baik (progresif) dengan recipe knowledge yang baru. Sebagai puncak dari transformasi progresif, para aktivis memperlihatkan diri sebagai agen perubahan, yaitu manusia yang bisa bekerja secara produktif, jujur, bersih dan profesional sekalipun mereka sebenarnya miskin dengan pengalaman sebagai politikus, namun sikap profesionalitasnya ini bahkan bisa mengalahkan anggota parlemen yang sudah malang melintang dalam dunia politik

Fenomena kehidupan aktivis sebagai manusia yang hidup dalam dunia pergerakan merupakan realitas penelitian yang sangat menarik dan kompleks dengan berbagai dinamikanya. Dengan mengintensifkan penelitian-penelitian tentang realitas aktivis yang dilakukan oleh ilmuwan komunikasi, diharapkan lahir berbagai konsep dan teoriteori komunikasi baru yang berperspektif ideologi pergerakan. Diharapkan, dari akumulasi studi-studi tentang komunikasi aktivis, akan lahir sebuah disiplin ilmu komunikasi baru dalam kontekas mikro, yaitu komunikasi pergerakan. Dengan demikian ilmu komunikasi sebagai salah satu bidang ilmu bisa melebarkan 'sayap' kajiannya ke wilayah-wilayah mikrokeilmuan.

\section{DAFTAR PUSTAKA}

Alwasila, A. Chaedar, 2003. Pokoknya Kualitatif: Dasar-dasar Merancang dan Melakukan Penelitian Kualitatif. Jakarta : Pustidaka Jaya

Basrowi \& Sukidin. 2002. Metode Penelitian Kualitatif: Perspektif Mikro. Surabaya: Insan

Berger, Peter L dan Thomas Luckman. 1990. "Tafsir Sosial atas Kenyataan: Risalah tentang Sosiologi Pengetahuan". Jakarta : Lembaga Penelitian, Pendidikan, dan Penerangan Ekonomi dan Sosial (LP3ES)

Blumer, Herbert. 1969. Symbolic Interactionism: Perspective and Method. New Jersey: Prentice Hall.

Bruinessen, Martin Van. 2002. Geneologies of Islamic Radicalism in PostSuharto Indonesia. South East Asia Research, 10,2, 2002.

Cresswell, W. John. 1998. Qualitative Inquiry and Research Design 
Choosing Among Five Traditions. California : Sage Publications. Inc.

Damanik, Ali Said, 2002. Fenomena Partai Keadilan: Transformasi 20 Tahun Gerakan Tarbiah di Indonesia. Jakarta : Teraju

Denzin, Norman K \& Yvonna S. Lincoln. 2000. Handbook of Qualitative Research. USA: Sage Publications.

Davis, Fred. 1972. Illness, Interaction and The Self. California: Wadsworth Publishing Company

Flick, Uwe, Erns von Kardoff \& Ines Steinke. 2004. A Companion to Qualitative Research. London: Sage Publication.

Goffman, Erving, 1959, The Presentation of Self in Everyday Life, Penguin Book, Cox \& Wyman Ltd. Great BBritain

Griffin E.M. 2000. A First Look at Communication Theory. USA ; The MacGraw-Hill.

Izutsu, Toshihiko. 1997. Relasi Tuhan dan Manusia. Penerjemah. Agus Fahri Husein dkk. Yogyakarta: PT. Tiara Wacana

Jalaluddin. 2005. Psikologi Agama. Jakarta: PT. Raja Grafindo Persada

Kuntowijoyo, 1993. Paradigma Islam: Interpretasi untuk Aksi. Bandung : Mizan
Lindlof, Thomas P., 1995. Qualitative Communication Research Methods, California USA: Sage Publication. Inc

Littlejohn, Stephen W. 2002. Theories of Human

Communication.

USA:Wadsworth

Publishing Company

Machmudi, Yon. 2005. Partai Keadilan Sejahtera: Wajah Baru Islam Politik Indonesia, Bandung : Harakatuna Publishing

Mulyana, Deddy, 2003, Metodologi Penelitian Kualitatif: Paradigma Baru Ilmu Komunikasi dan Ilmu Sosial Lainnya. Bandung: Rosda - 2002. Ilmu Komunikasi: suatu Pengantar. Bandung: Rosda . 1999. Nuansa-Nuansa Komunikasi. Bandung: Rosda

Musgrove, Frank, 1977. Margin of The Mind. London: Methuen \& Co LtD

Schutz, Alfred. Translated by George Walsh and Frederick Lehnert. 1972. The Phenomenology of the Social World. London: Heinemann Educational Books Ltd. 